\title{
Pyridine Nucleotide Charge Reduces Photosynthesis under Short-term Oxygen Deficiency
}

\author{
Manuela Zude-Sasse ${ }^{1}$ \\ Institute of Agricultural Engineering Bornim e.V., Max-Eyth-Allee 100, 14469 Potsdam-Bornim, \\ Germany \\ Ulrich Hartmond \\ Citrus Research and Education Center, University of Florida, 700 Experiment Station Road, Lake Alfred, \\ FL 33850 \\ Georg Ebert and Peter Lüdders \\ Department of Fruit Science, Humboldt University of Berlin, Albrecht-Thaer-Weg 3, 14195 Berlin, \\ Germany
}

\begin{abstract}
AdDitional InDEX wORDs. chlorophyll fluorescence, NAD, NADP, oxygen deficiency, pyridine nucleotide charge, Mangifera indica

Abstract. Soil flooding reduces partial pressure of oxygen $\left(\mathrm{pO}_{2}\right)$ in the root zone and often results in a reduction in photosynthesis and growth. In greenhouse studies, rooted stem cuttings of the mango (Mangifera indica $\mathbf{L}$.) rootstock selection 13/1 were exposed to anoxia by saturating the root zone with $\mathrm{N}_{2}$ for up to $52 \mathrm{~h}$. Reduced $\mathrm{pO}_{2}$ in the root zone affected the energy status of the roots and particularly enhanced the phosphorylated and nonphosphorylated pyridine nucleotide charges - the ratio of reduced Nicotinamide-adenine-dinucleotides $[N A D(P) H]$ to total Nicotinamide-adenine-dinucleotide content [oxidized $\mathrm{NAD}(\mathrm{P})^{+}$plus $\left.\mathrm{NAD}(\mathrm{P}) \mathrm{H}\right]$ — that drive the redox reaction rates in cell metabolism. Also, the pyridine nucleotide charges in leaves were enhanced, while the photosynthetic rate decreased following reduction in $\mathrm{pO}_{2}$ in the root zone. During up to $4 \mathrm{~h}$ of reduced $\mathrm{pO}_{2}$, the ratio of internal $\mathrm{CO}_{2}$ concentration in the mesophyll to ambient $\mathrm{CO}_{2}$ concentration was unchanged. This implies a nonstomatal influence on photosynthesis. In addition, light saturation of photosystem II occurred at lower irradiance $\left(470 \mu \mathrm{mol} \cdot \mathrm{m}^{-2} \cdot \mathrm{s}^{-1}\right)$ resulting in reduced maximum photochemical efficiency below that of the high $\mathrm{pO}_{2}$ controls. After $28 \mathrm{~h}$ of reduced $\mathrm{pO}_{2}, \mathrm{NAD}(\mathrm{P})$ charges in the leaves returned to normal, diminishing its potential effect on net photosynthetic rate.
\end{abstract}

Reduced partial pressure of oxygen $\left(\mathrm{pO}_{2}\right)$ in the root zone leads to decreased root respiration due to the absence of the terminal electron receptor (Crawford, 1993). Subsequently, ATP synthesis and nicotinamid-adenosin-dinucleotide (NADH) oxidation decrease in the mitochondria (Crawford, 1993; Kwast and Hand, 1996). Within several hours of anoxic conditions less efficient anaerobic respiration pathways are initiated that yield significantly less energy in the form of ATP (Perata and Alpi, 1993). Limited ATP synthesis has frequently been studied (Crawford, 1993; Dry and Wiskich, 1982), but little information is available on the changes in the pyridine nucleotide charge (Backhausen et al., 1998). It has been hypothesized that lack of oxygen (anoxia) in the root zone causes an end-product inhibition of the flavoproteine-bound NADH oxidation located at the mitochondrial cristae (Möller and Lin, 1986; Peine et al., 1985). Kwast and Hand (1996) showed a significant increase in the concentration of reduced NADH and the pyridine nucleotide charge (NADH/ $\left.\left[\mathrm{NAD}^{+}+\mathrm{NADH}\right]\right)$ in isolated mitochondria exposed to anoxia.

Flooding-induced anoxia in the root zone usually causes a rapid reduction in the photosynthetic rate of mango (Magnifera indica L.) (Larson and Schaffer, 1991). The reduction in net photosynthesis $\left(\mathrm{P}_{\mathrm{N}}\right)$ appears to be largely the result of stomatal closure due to enhanced ethylene or abscisic acid (ABA) production, resulting in reduced $\mathrm{CO}_{2}$ uptake (Bradford and Hsiao, 1982). The rate of ATP and NADPH formation in the leaves constitute

Received for publication 11 Sept. 2000. Accepted for publication 18 July 2001. The cost of publishing this paper was defrayed in part by the payment of page charges. Under postal regulations, this paper therefore must be hereby marked as advertisement solely to indicate this fact.

${ }^{1}$ Corresponding author. the driving force of photosynthesis (Gerst et al., 1994; Giersch et al., 1980; Laisk et al., 1991; Siebke et al., 1990). By comparison, a change in the availability of inorganic phosphate $\left(\mathrm{P}_{\mathrm{i}}\right)$ in the chloroplasts has marginal effects on steady state photosynthesis under anoxia in the root zone (Rao and Terry, 1994). A number of studies suggest a major influence of the degree of ADP phosphorylation regulated via the carbohydrate concentration of plants (Rao et al., 1990) and concluded that the rate of NADP reduction regulates photosynthesis (Backhausen et al., 1998; Giersch et al., 1980; Hanning and Heldt, 1993; Heineke et al., 1991; Krömer, 1995; Laisk et al., 1991; Siebke et al., 1990; Wigge et al., 1993). In their model, the pyridine nucleotide charge $\left[\right.$ anabolic reduction charge $(\mathrm{ARC})=\mathrm{NADPH} /\left(\mathrm{NADPH}+\mathrm{NADP}^{+}\right)$ and catabolic reduction charge $\left.(\mathrm{CRC})=\mathrm{NADH} /\left(\mathrm{NADH}+\mathrm{NAD}^{+}\right)\right]$ determines the electron transport rate in the two photosystems (PSI and PSII) in the chloroplasts. Subsequently, the increased NADPH concentration and the deficiency of $\mathrm{NADP}^{+}$could limit the photosynthetic rate under anoxia.

Lack of $\mathrm{O}_{2}$ as electron receptor in the respiratory chain probably causes a decrease in the oxidation of pyridine nucleotides in the roots (Kwast and Hand, 1996; Peine et al., 1985). Studies in wheat (Triticum aestivum L.) found a shift from $\mathrm{NADP}^{+}$to reduced NADPH throughout the plant under conditions of reduced $\mathrm{pO}_{2}$ in the root zone, and it was suggested that this increase in the pyridine nucleotide charge was responsible for reduced $\mathrm{P}_{\mathrm{N}}$ under anoxia (Hoffmann et al., 1993; Peine et al., 1985).

In the present study we investigated the pyridine nucleotide charge in root and leaf tissue of mango under reduced $\mathrm{pO}_{2}$ in the root zone and its association with $\mathrm{CO}_{2}$ gas exchange in the leaves. The objective of the study was to demonstrate that an increase in 
the pyridine nucleotide charge in leaves results in a nonstomatal reduction in $\mathrm{P}_{\mathrm{N}}$ of mango under anoxia.

\section{Materials and Methods}

Rooted stem cuttings of mango (Mangifera indica L., rootstock ' $13 / 1$ ') with well developed root systems and shoots that produced four to five flushes per year, were selected for uniformity from material grown in a greenhouse at the Department of Fruit Science, Humboldt University of Berlin, Germany. Two plants each were grown in 5.6-L plastic containers $(40 \mathrm{~cm}$ in length, $3.5 \mathrm{~cm}$ in width, $40 \mathrm{~cm}$ in height) filled with sterilized quartz sand (0.3- to $0.8-\mathrm{mm}$ grains in the top and 2.0 - to $3.5-\mathrm{mm}$ grains in the bottom third of containers) (Zude-Sasse et al., 1998). Containers were insulated and covered to maintain root temperature at $22 \pm 1{ }^{\circ} \mathrm{C}$ during the course of the experiments. Plants were fertigated daily through a drip irrigation system using $0.3 \%$ Wuxal nutrient solution (6N-4P-8K, Aglukon, Düsseldorf, Germany) adjusted to $\mathrm{pH} 6.3$ with $\mathrm{H}_{2} \mathrm{SO}_{4}$, and received supplementary light $\left(500 \mu \mathrm{mol} \cdot \mathrm{m}^{-2} \cdot \mathrm{s}^{-1}\right)$ for $12 \mathrm{~h} \cdot \mathrm{d}^{-1}(\mathrm{HQI}-\mathrm{TS} 400 \mathrm{~W} / \mathrm{D}$, Osram, Munich, Germany).

Anoxia in the root zone was induced by injecting humidified $\mathrm{N}_{2}$ from a gas cylinder (Messer, Griessheim, Germany) into the root containers through 5-mm-i.d. polyvinyl chloride tubing attached to three valves at the bottom of each pot. The sand in containers for control plants was injected with humidified ambient air at the same flow rate $\left(1.5 \mathrm{~L} \cdot \mathrm{min}^{-1}\right)$, which was controlled by a mass flow meter (Obold, Hofheim/Ts., Germany). During treatment, the shoots were well ventilated with fans to prevent environmental changes due to $\mathrm{N}_{2}$ gassing out from the sand. Anoxia treatments lasted 2, 4, 28, and $52 \mathrm{~h}$ and were each performed on four replicate plants (total of 20 plants in 10 containers), and the experiment was conducted three times.

Chlorophyll Fluorescence analysis. Chlorophyll fluorescence was determined using a Mini-Pam fluorometer (Walz, Effeltrich, Germany) for pulse amplitude modulated measurements (White and Critchley, 1999). A halogen lamp (Osram) was used to produce photosynthetically active [actinic (A)] radiation $(P A R)$ (400 to $700 \mathrm{~nm}$ ) of $600 \mu \mathrm{mol} \cdot \mathrm{m}^{-2} \cdot \mathrm{s}^{-1}$. To achieve light saturation $(\mathrm{S}), 0.8-\mathrm{s}$ pulses at an irradiance of $5000 \mu \mathrm{mol} \cdot \mathrm{m}^{-2} \cdot \mathrm{s}^{-1}$ were provided at 30-s intervals (Zude-Sasse, 1999). During measurements, chlorophyll fluorescence was continuously recorded digitally by computer. Light saturation curves were recorded before anoxia treatments according to Gerst et al. (1994). Recordings on anoxia treated and nontreated aerated control plants were taken at noon on leaves that were first adapted to dark conditions for $15 \mathrm{~min}$.

Maximum photochemical yield ( $y$ ) of dark-adapted leaves was determined by calculating the quotient of variable $\left(\mathrm{F}_{\mathrm{V}}\right.$ $\left.=\mathrm{F}_{\mathrm{M}}-\mathrm{F}_{0}\right)$ to maximum fluorescence $\left(y=\mathrm{F}_{\mathrm{V}} / \mathrm{F}_{\mathrm{M}}\right)$. Changes in the electron transport rate (ETR) in response to anoxia were determined on light adapted leaves by multiplying the efficient quantum yield $\left[\mathrm{F}=\left(\mathrm{F}_{\mathrm{M}}{ }^{\prime}-\mathrm{F}_{\mathrm{T}}\right) / \mathrm{F}_{\mathrm{M}}{ }^{\prime}\right]$ with the actual PAR, using a factor of 0.84 for leaf absorption and a factor of 0.5 to account for the two photosystems $($ ETR $=$ F.PAR $\cdot 0.84 \cdot 0.5)$.

$\mathrm{Co}_{2}$-Gas exchange. Carbon dioxide and $\mathrm{H}_{2} \mathrm{O}$ vapor exchange of attached, mature (2- to 5-month-old) leaves (n $=24$ ) were measured with a portable photosynthesis system (CI-301PS, CID Inc., Vancouver, Wash.) and a 11-cm leaf cuvette (CI-301LC-2, CID) at $500 \mu \mathrm{mol} \cdot \mathrm{m}^{-2} \mathrm{~s}^{-1}$. $\mathrm{P}_{\mathrm{N}}$ under steady-state conditions, internal $\mathrm{CO}_{2}$ concentration $\left(\mathrm{c}_{\mathrm{i}}\right)$, ambient $\mathrm{CO}_{2}$ concentration $\left(\mathrm{c}_{\mathrm{a}}=375 \mu \mathrm{mol} \cdot \mathrm{mol}^{-1}\right)$, and stomatal conductance were calculated automatically by the CI-301PS program functions.

ROOT RESPIRATION. Root respiration measurements were performed on 5-cm-long root segments $(n=6)$ that were excised $1 \mathrm{~cm}$ from the root tip and enclosed in a 50-mL cuvette, using an infrared $\mathrm{CO}_{2}$ gas analyzer (ADC, Herts, United Kingdom) (Lambers et al., 1991). Air volume in the soil was determined at the end of each experiment as the difference between actual soil water content and saturated water content. The partial pressure of $\mathrm{O}_{2}$ in the root zone was measured with a paramagnetic oxygen analyzer (PMA 10, M\&C Products, Ratingen, Germany).

Pyridine nuCleotide Content. NAD and NADP levels in the roots were determined enzymatically (Brinkman et al., 1973; Zhao et al., 1987; Zude-Sasse and Lüdders, 2000). The oxidized $\mathrm{NADP}^{+}$is stable at low $\mathrm{pH}$, whereas reduced NADPH is present under alkaline conditions. For $\mathrm{NAD}^{+}$and $\mathrm{NADP}^{+}$analyses, $5 \mathrm{~g}$ of the fine root system of each plant was extracted with $20 \mathrm{~mL}$ perchloric acid. NADH and NADPH were extracted in $\mathrm{KOH}$. After extraction, samples were homogenized (Ultra-turrax T25, Jahnke\&Kunkel Labortechnik, Staufen i. B., Germany), heated $\left(60{ }^{\circ} \mathrm{C}\right)$ for $30 \mathrm{~min}$, and centrifuged for $10 \mathrm{~min}$ at $3500 \mathrm{~g}_{n}$ (Labofuge GL, Kendro Laboratory Products, Hanau, Germany). Supernatants of oxidized pyridine nucleotides were neutralized with $\mathrm{KOH}$ and adjusted to $\mathrm{pH} 7.4$ with Tris- $\mathrm{HCl}$ at $1 \mathrm{~mol} \cdot \mathrm{L}^{-1}$. Supernatants of the reduced pyridine nucleotides were neutralized with $\mathrm{HCl}$ and adjusted to $\mathrm{pH} 7.6$ with tri-ethanolamine (TEA) at $1 \mathrm{~mol} \cdot \mathrm{L}^{-1}$ (Zhao et al., 1987).

Nonphosphorylated and phosphorylated pyridine nucleotides were assayed within $2 \mathrm{~h}$ measuring the specific enzymatic reduction of NAD and NADP with alcohol dehydrogenase and glucose6-phosphate dehydrogenase, respectively (Brinkman et al., 1973; Zude-Sasse, 1999). A coupled colorimetric reaction with 2,5cyclohexadien-1-one,2,6-dichloro-4-[(4-hydroryphenyl)-imino] and phenazinium,5-methyl,methyl sulfate was recorded spectrophotometrically (SP8-300, Unicam Chromatography, Cambridge, United Kingdom) at $625 \mathrm{~nm}$. All chemicals and enzymes were purchased from Boehringer-Mannheim (Hoffmann-La Roche, Basel, Switzerland). The pyridine nucleotide concentration of samples was calculated based on $83 \%$ recovery and extinction of

Fig. 1. Effect of reduced $\mathrm{pO}_{2}$ in the root zone on root respiration of '13/1' mango rootstock. Anoxia was induced at $0500 \mathrm{HR}(\downarrow)$, the light period started at 0600 HR. Vertical bars indicate SE $(n=4)$.

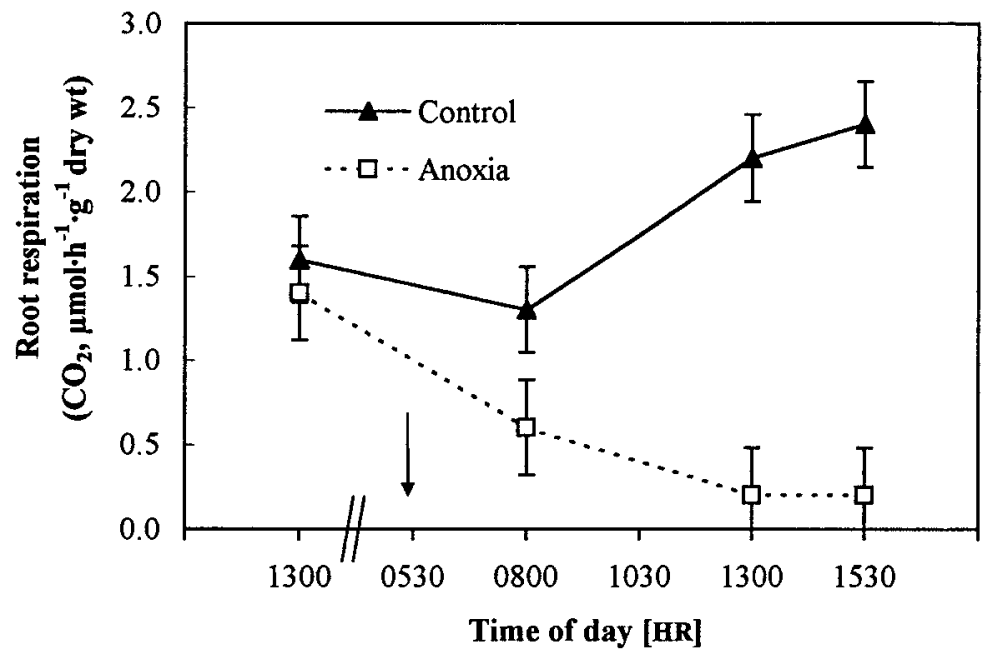




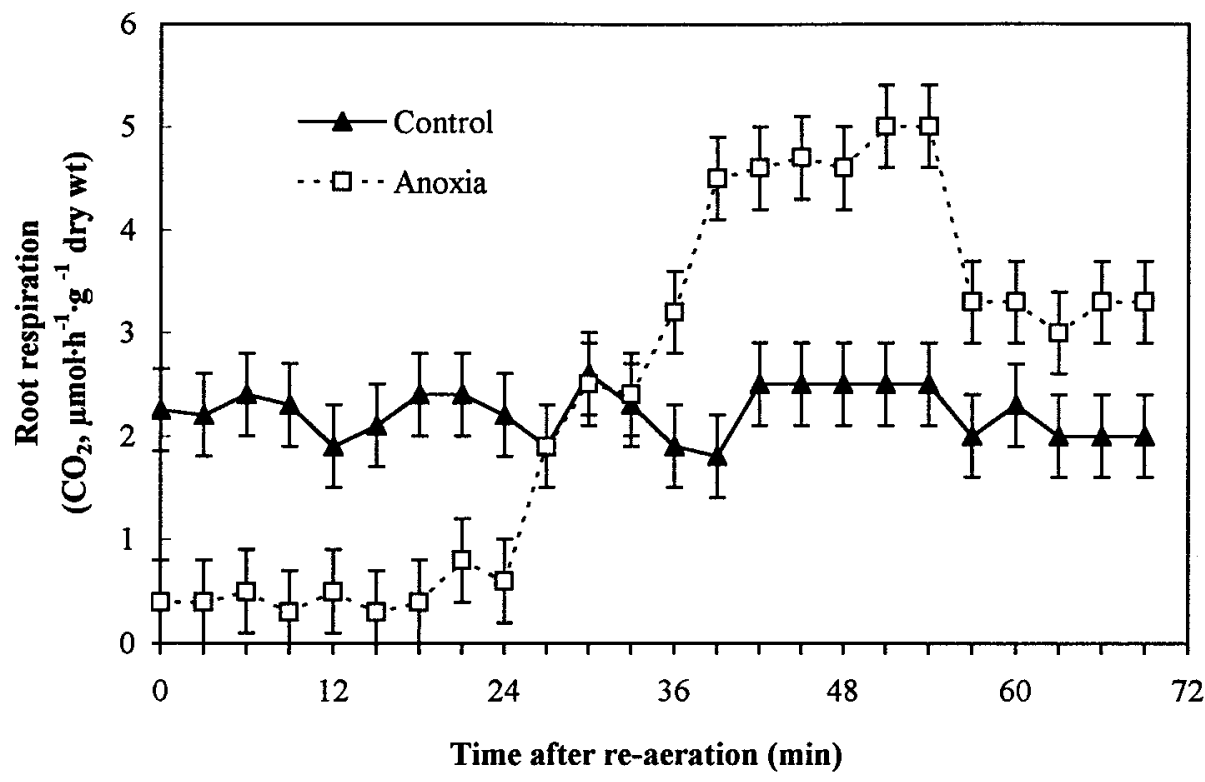

Fig. 2. Root respiration of ' $13 / 1$ ' mango rootstock following re-aeration of the root zone after $8 \mathrm{~h}$ of anoxia. Vertical bars indicate $\mathrm{SE}(n=6)$.

standard pyridine nucleotide solutions (Zude-Sasse, 1999). Redox potential $\left(\mathrm{E}_{\mathrm{h}}\right)$ of the NADPH/NADP ${ }^{+}$redox system was calculated from the NADP concentration.

Experiments were analyzed as a randomized complete block design with four replications. All data were analyzed statistically using analysis of variance procedures or regression analysis (SAS Software, SAS Inst. Inc., Cary, N.C.), and means were compared using Duncan's multiple range test, $P \leq 0.05$ or 0.01 .

\section{Results}

Oxygen Partial Pressure. The growing media had a total pore volume of $29 \% \pm 4 \%$. Soil water content during the experiments was $6 \% \pm 1 \%$ and no significant water loss was measured due to flow of the saturated air or $\mathrm{N}_{2}$ through the cuvette. The $\mathrm{pO}_{2}$ in the control containers was $21 \mathrm{MPa}$, which was reduced by the $\mathrm{N}_{2}$ treatment to $0 \mathrm{MPa}$ within $30 \mathrm{~s}$.

RoOT RESPIRATION. At $\mathrm{pO}_{2}=21 \mathrm{MPa}$, respiration of excised root segments increased during the day, while at reduced $\mathrm{pO}_{2}$ root respiration decreased (Fig. 1). When the cuvettes were aerated following $8 \mathrm{~h}$ of anoxic conditions, root respiration rates started to increase after 23 min reaching $200 \%$ of control levels after 39 min (Fig. 2). Fiftyfour minutes after the end of treatments, rates decreased again but remained higher than the control during the measuring period of $70 \mathrm{~min}$.

Photosynthesis. Limited $\mathrm{pO}_{2}$ in the root zone reduced $\mathrm{P}_{\mathrm{N}}$ within $2.5 \mathrm{~h}$ (Fig. 3) and depressed the diurnal pattern of gas exchange (Fig. 4). Continued exposure to anoxia for up to $52 \mathrm{~h}$ further reduced $\mathrm{CO}_{2}$ gas exchange (Fig. 3). The ratio of the $\mathrm{CO}_{2}$ concentration in the mesophyll $\left(\mathrm{c}_{\mathrm{i}}\right)$ and ambient air $\left(\mathrm{c}_{\mathrm{a}}\right)$ was not affected by anoxia until $28 \mathrm{~h}$ when $\mathrm{c}_{\mathrm{i}}: \mathrm{c}_{\mathrm{a}}$ was increased relative to the control (Fig. 3).
Chlorophyll Fluorescence. With the duration of anoxia, dark fluorescence tended to increase from $\mathrm{F}_{0}=148$ to $\mathrm{F}_{0}=208$ and maximum photochemical efficiency of photosystems decreased from $y=0.81$ to $y=$ 0.70 within $2 \mathrm{~h}$. Although variable and statistically nonsignificant, $\mathrm{F}_{0}$ increased by $26 \%$ while $y$ was reduced by $8 \%$ after $4.5 \mathrm{~h}$ of reduced $\mathrm{pO}_{2}$. Maximum effective photochemical efficiency of greenhouse acclimated mango plants was derived from the inflection point of the regression curve for electron transport rate (ETR) and was reached at $550 \pm 30 \mu \mathrm{mol} \cdot \mathrm{m}^{-1} \cdot \mathrm{s}^{-1}$ (Fig. 5). At irradiances $>480 \mu \mathrm{mol} \cdot \mathrm{m}^{-2} \cdot \mathrm{s}^{-1}$, ETR was significantly limited by reduced $\mathrm{pO}_{2}$ in the root zone.

Pyridine nucleotide content. Under nonstressed conditions, the nucleotide content and reduction charge of NADP (ARC) and NAD (CRC) in leaves were increased by light conditions but not in roots (Table 1). Two days of anoxia in the roots caused increased concentrations of NADP and reduced concentrations of NAD in the leaves (Table 2). However, in roots both, NADP and particularly NAD concentrations were increased compared to nonstressed mango plants. Anoxia resulted in increased ARC and CRC throughout the plant (Table 3). After $4 \mathrm{~h}$ of anoxia the redox potential $\left(\mathrm{E}_{\mathrm{h}}\right)$ of the NADP redox system decreased from $-315 \mathrm{mV}$ to $-324 \mathrm{mV}$ in the roots and from $-312 \mathrm{mV}$ to $-320 \mathrm{mV}$ in the leaves.

\section{Discussion}

Use of nitrogen gas instead of water to replace soil $\mathrm{O}_{2}$ to study anoxia has several advantages: $\mathrm{pO}_{2}$ in the soil is reduced within a very short time, and there are no changes in soil microbial respiration that could affect root respiration measurements (Trolldenier and Hecht-Buchholz, 1984; Zude-Sasse et al., 1998).

Fig. 3. Effect of short-term and midterm reduced $\mathrm{pO}_{2}$ in the root zone of ' $13 / 1$ ', mango rootstock on net photosynthesis $\left(\mathrm{P}_{\mathrm{N}}\right)$ and the ratio of $\mathrm{CO}_{2}$ in the mesophyll $\left(\mathrm{c}_{\mathrm{i}}\right)$ and in the ambient air $\left(\mathrm{c}_{\mathrm{a}}\right)$. Anoxia was induced at $0500 \mathrm{HR}$. Vertical bars indicate SE $(\mathrm{n}=4)$.

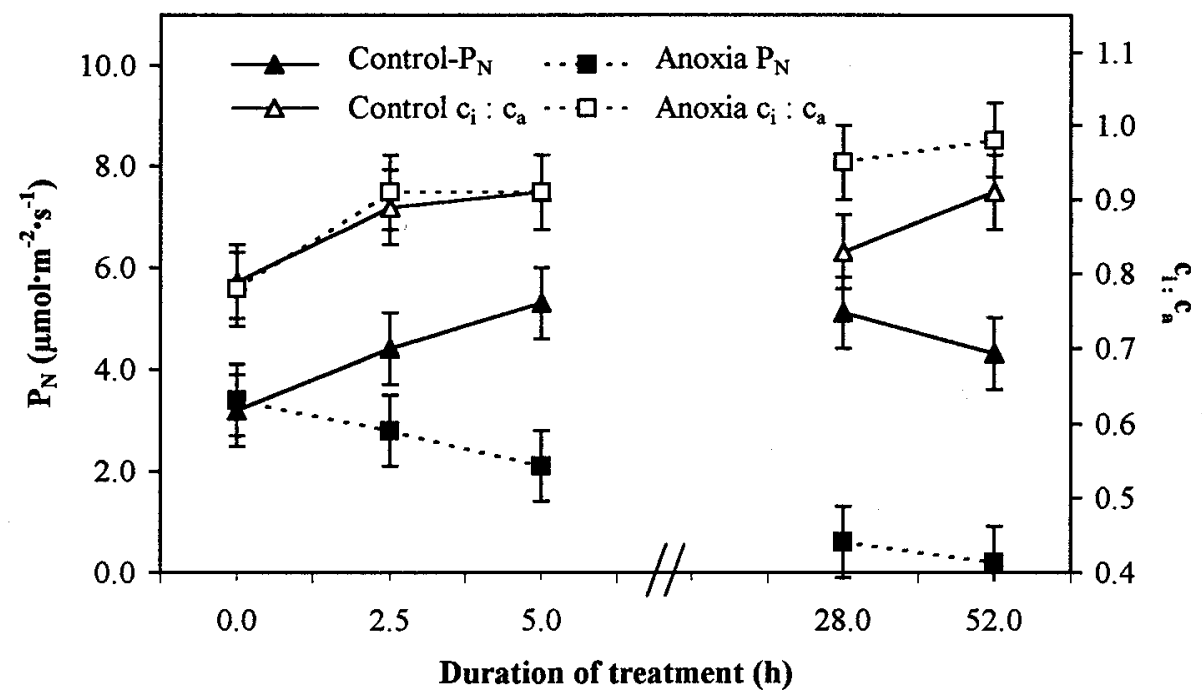




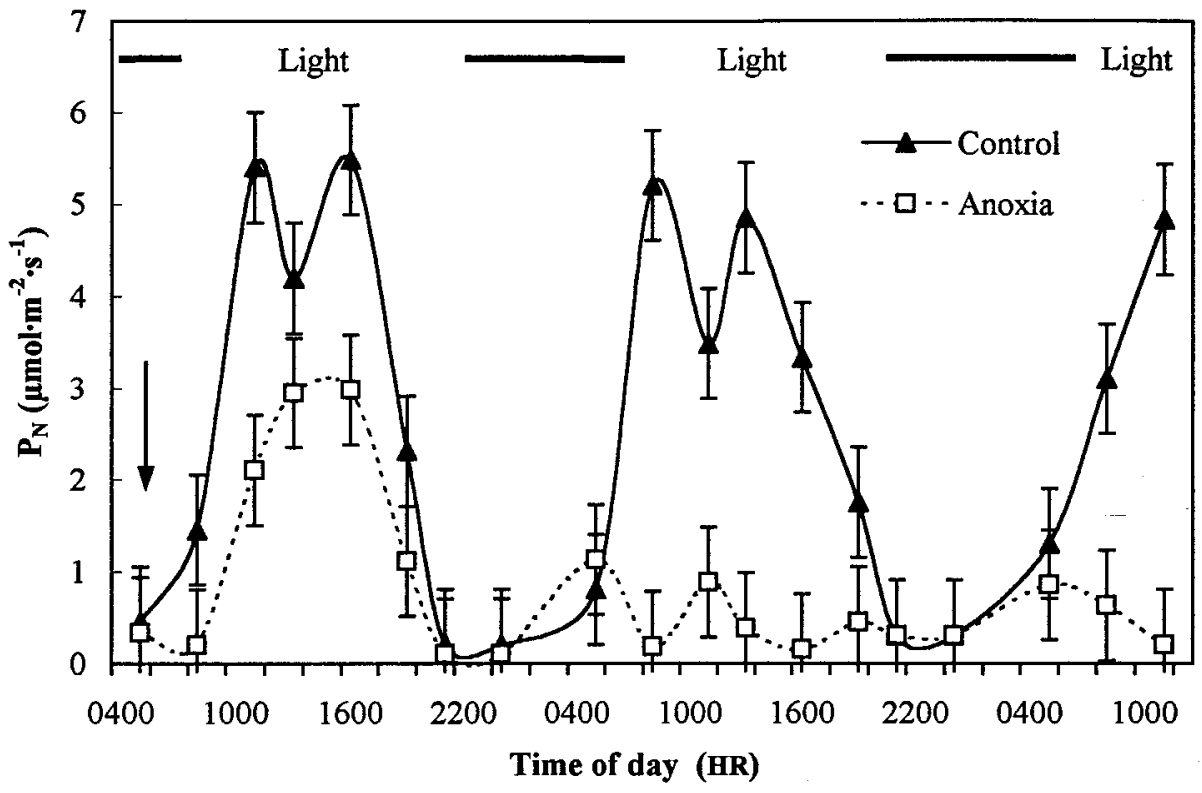

Fig. 4. Effect of reduced $\mathrm{pO}_{2}(24 \mathrm{~h})$ on diurnal pattern of net photosynthesis $\left(\mathrm{P}_{\mathrm{N}}\right)$ of ' $13 / 1$ ' mango rootstock. Anoxia was induced at $0500 \mathrm{HR}(\downarrow)$. Measurements were taken at $500 \mu \mathrm{mol} \cdot \mathrm{m}^{-2} \cdot \mathrm{s}^{-1} P A R$ between 0700 and $1900 \mathrm{HR}$, and $360 \pm 10$ $\mu \mathrm{mol} \cdot \mathrm{mol}^{-1}$ ambient $\mathrm{CO}_{2}$ concentration. Vertical bars indicate $\mathrm{SE}(\mathrm{n}=4)$.

Additionally, changes in mineral nutrient availability due to increased reduction potential in the root zone are averted (Larson, 1992; Ponnamperuma, 1972), and no $\mathrm{CO}_{2}$ accumulation occurs in the root zone that could affect soil $\mathrm{pH}$ and respiration (McIntyre and McNeil, 1997; Summers and Jackson, 1996). Thus, the effect of anoxia on the energy status was isolated from potential side effects, and results should be more generally applicable to conditions of low $\mathrm{pO}_{2}$ in the root zone.

EFFECT OF ANOXIA ON THE ENERGY STATUS OF ROOTS. Under aerobic conditions, mango exhibited a typical diurnal pattern of root respiration that was probably a function of carbohydrate availability (Lambers et al., 1991). Under anaerobic conditions (anoxia), root respiration was severely limited by the lack of $\mathrm{O}_{2}$ as the terminal electron receptor. Reaeration of the root zone resulted in an increase of the respiration rate above that of nontreated roots. Biemelt et al. (1998) described a similar overcompensation phenomenon for respiration rates previously reduced under anoxia. Limited respiration during anoxia depresses the energy status of roots (Crawford, 1993; Lambers et al., 1991). Reduced phosphorylation of ADP to ATP under anoxia has been attributed to reduced oxidative phosphorylation in mitochondria (Pradet and Raymond, 1983). This reduction in carbon metabolism (Crawford, 1993; Hand and Hardewig, 1996) was associated with reduced root growth (Lambers et al., 1991).

Under anoxia, oxidation of NADH in the mitochondria (respiration) was diminished. In isolated mitochondria, a dramatic increase in the NAD charge was found within 10 to 30 min (Kwast and Hand, 1996; Paul and Schneckenburger, 1996; Wigge et al., 1993) with the redox system of NAD almost completely reduced under anoxia.

In our experiments, an increased NAD and NADP charge in the roots was found after $2 \mathrm{~h}$ of reduced $\mathrm{pO}_{2}$. During aerobic respiration as well as fermentation processes, $2 \mathrm{~mol}$ of NADH are oxidized per mol of glucose. After $400 \mathrm{~min}$ of anoxia, fermentation in wheat reached a level that could affect oxidation of NADH (Brändle, 1991; Brändle personal communica- tion, 1999). We measured short-term and midterm $(28 \mathrm{~h})$ increases of $\mathrm{CRC}$ in the roots (Table 3 ). The reduction of $\mathrm{NAD}^{+}$to $\mathrm{NADH}$ during glycolysis was assumed to continue under anaerobic conditions (Drew, 1997; Perata and Alpi, 1993). We did observe a slight compensation for the NAD reduction rate through fermentation.

NADP is reduced during direct oxidation of glucose in the cytoplasm (pentose phosphate cycle), whereas NADPH is oxidized enzymatically without involvement of $\mathrm{O}_{2}$. This oxidation has been associated with lipid synthesis in the peroxisomes (Kennedy et al., 1992; Pfister-Sieber and Brändle, 1994; Ricard et al., 1994). Activation of this oxidative pathway is likely one metabolic adaptation to anoxia (Andrews et al., 1994). The rate of NADP reduction has been recognized as an indicator for tolerance of a plant to anoxia in the root zone (Kennedy et al., 1991; Rumpho and Kennedy, 1983a, 1983b). In the present study, low $\mathrm{pO}_{2}$ in the roots decreased overall metabolism, which was associated with reduced NADP-oxidation. A short-term increase of the NADP reduction rate could possibly be alleviated temporarily by an increased protein and lipid production for anaerobic metabolism.

The accumulation of pyridine nucleotides in their reduced form increased the reduction pressure calculated as redox potential. Pyridine nucleotides represent the terminal electron donor for root metabolism $\left(\mathrm{E}_{0}=-320 \mathrm{mV}\right.$ ) (Hanning and Heldt, 1993). Under reduced $\mathrm{pO}_{2}$, reactions that involve electron transfer from NADH to an enzyme or metabolite are more exergonic. This was confirmed in the present study by a decreasing NADP redox potential from 315 to $-324 \mathrm{mV}$ under reduced $\mathrm{pO}_{2}$. However, this reduction pressure cannot be utilized in high amounts by enzymatic pathways due to decreased carbohydrate metabolism in the citrate cycle under anoxia. Particularly, activity of reductases could be enhanced by the excess energy source (Popova and Pinheiro de Carvalho, 1998; Scheibe, 1991; Zude-Sasse and Lüdders, 2000).

Fig. 5. Effect of reduced $\mathrm{pO}_{2}$ in the root zone for $4.5 \mathrm{~h}$ with increasing photosynthetic photon flux $(P P F)$ on the electron transport rate (ETR) in leaves of greenhousegrown '13/1' mango. Light saturation was derived from the inflection point of the regression curve $\left(\uparrow, 550 \pm 30 \mu \mathrm{mol} \cdot \mathrm{m}^{-2} \cdot \mathrm{s}^{-1}\right)$. Vertical bars indicate SE $(n=4)$.

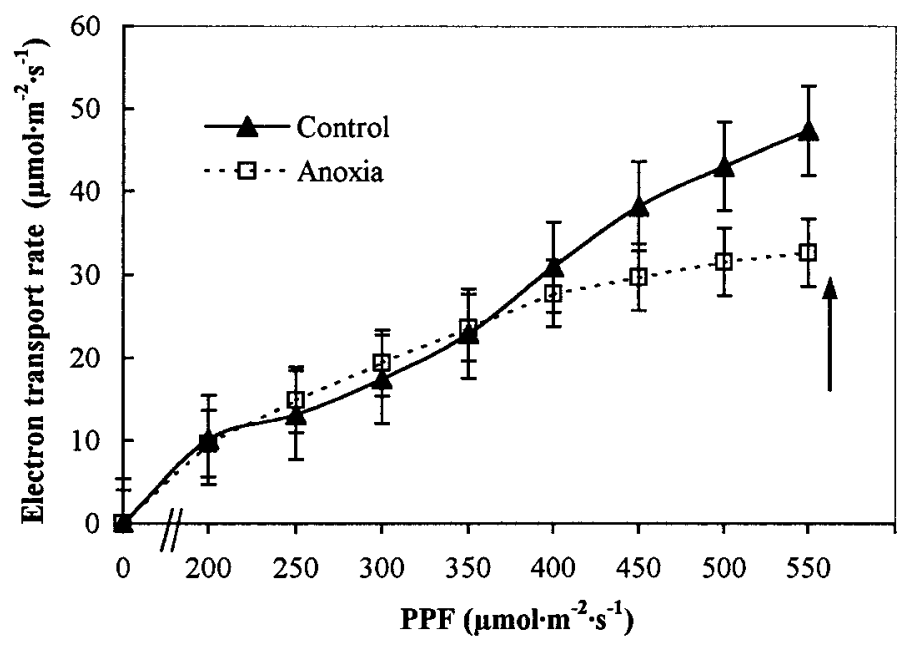


Table 1. Pyridine nucleotide content of nonstressed roots and leaves of '13/1' mango, and NADP charge (ARC) and NAD charge (CRC) measured under light $(1100 \mathrm{HR})$ and dark $(2100 \mathrm{HR})$ conditions $(\mathrm{n}=4)$.

\begin{tabular}{lcccccc}
\hline & & \multicolumn{4}{c}{ Nucleotide content $\left(\mathrm{nmol} \cdot \mathrm{g}^{-1}\right.$ fresh wt) } \\
\cline { 3 - 7 } Tissue & Treatment & NADP & NADPH & ARC & NAD & NADH \\
\hline Leaves & Light & $134^{\mathrm{z}}$ & 124 & 0.48 & 390 & 230 \\
& Dark & $180^{* *}$ & $114^{*}$ & 0.39 & $362^{* *}$ & $136^{* *}$ \\
\multirow{2}{*}{ Roots } & Light & 143 & 102 & 0.41 & 207 & 0.37 \\
& Dark & 112 & 200 & 0.64 & 240 & 0.27 \\
& & & & & 0.33 \\
\hline
\end{tabular}

${ }^{\overline{\mathrm{z}}}$ Mean separation within columns for leaves or roots by Duncan's multiple range test at $P=0.05(*)$ or $0.01(* *)$.

Table 2. Relative change of pyridine nucleotide content of leaves and roots of ' $13 / 1$ ' mango under conditions of reduced $\mathrm{pO}_{2}$ in the root zone ( $\mathrm{n}=4$ ).

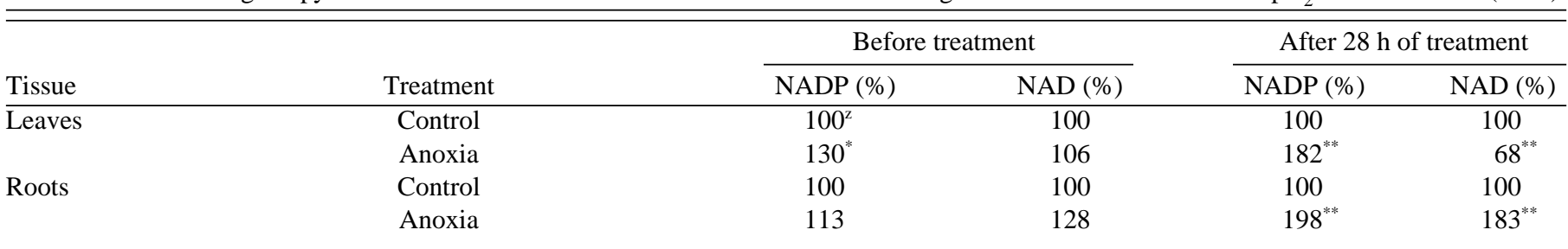

${ }^{\bar{z}}$ Mean separation within columns for leaves or roots by Duncan's multiple range test at $P=0.05(*)$ or $0.01(* *)$.

Table 3. Effect of 2, 4, and $28 \mathrm{~h}$ of reduced $\mathrm{pO}_{2}$ in the root zone on NADP charge (ARC) and NAD charge (CRC) in roots and leaves of '13/1' mango. Anoxia was started at $0500 \mathrm{HR}(\mathrm{n}=4)$.

\begin{tabular}{|c|c|c|c|c|c|c|c|}
\hline \multirow[b]{3}{*}{ Treatment } & \multirow[b]{3}{*}{ Tissue } & \multicolumn{6}{|c|}{ Reduced $\mathrm{pO}_{2}$ in the root zone } \\
\hline & & \multicolumn{2}{|c|}{$2 \mathrm{~h}$} & \multicolumn{2}{|c|}{$4 \mathrm{~h}$} & \multicolumn{2}{|c|}{$28 \mathrm{~h}$} \\
\hline & & ARC & CRC & ARC & $\mathrm{CRC}$ & ARC & CRC \\
\hline \multirow[t]{2}{*}{ Leaves } & Control & $0.39^{\mathrm{z}}$ & 0.27 & 0.38 & 0.34 & 0.39 & 0.29 \\
\hline & Anoxia & $0.44^{*}$ & $0.35^{*}$ & $0.53^{*}$ & $0.48^{*}$ & 0.43 & 0.35 \\
\hline \multirow[t]{2}{*}{ Roots } & Control & 0.54 & 0.45 & 0.46 & 0.39 & 0.52 & 0.42 \\
\hline & Anoxia & $0.79^{*}$ & $0.57^{*}$ & $0.57^{*}$ & $0.54^{* *}$ & 0.59 & $0.56^{*}$ \\
\hline
\end{tabular}

${ }^{\mathrm{z}}$ Mean separation within columns for leaves or roots by Duncan's multiple range test at $P=0.05(*)$ or $0.01(* *)$.

EFFECT OF ANOXIA ON THE PYRIDINE NUCLEOTIDE CHARGE IN LEAF TISSUE. The short-term increase of the NAD and NADP charge in the roots was associated with an increase of NAD and NADP charge in leaves of mango (Table 3). Increased total NADP concentration in the leaf (Table 2) was possibly a result of enhanced ARC and could be interpreted as compensation for the shortage of $\mathrm{NADP}^{+}$. This supports our hypothesis that $\mathrm{NADP}^{+}$is deficient under anoxia. Similarly, NADP concentrations typically increase with the onset of photosynthesis in light (Gerst et al., 1994; Kitzmann, 1996; Rao et al., 1990; Wigge et al., 1993). Another potential mode of action could involve transhydrogenase that shifts total pyridine nucleotides from NAD to NADP (Peine et al., 1985; Rao et al., 1990).

EFFeCT OF ANOXIa ON $\mathrm{CO}_{2}$ EXChange OF THE LEAVES. Carbon dioxide exchange of mango leaves was reduced significantly under anoxia (Fig. 3). Although this phenomenon has been shown in a number of studies (Andersen et al., 1984; Beckman et al., 1992; Bradford and Hsiao, 1982; Larson, 1992; Larson and Schaffer, 1991; Pezeshki et al., 1996; Vu and Yelenosky, 1991), the reasons for this are still unclear (Schaffer et al., 1994).

Stomatal EFFects on PHotosynthesis. Reduced stomatal conductivity is commonly discussed as the cause for reduced $\mathrm{CO}_{2}$ exchange under anoxia (Jackson and Drew, 1984; Pezeshki et al., 1996; Schaffer et al., 1994). Under anoxia, however, $c_{i}$ is either increased (Vu and Yelenoski, 1991) or unchanged (Beckman et al., 1992; Pezeshki et al., 1996). In mango, we measured a temporary reduction in stomatal conductance that was associated with a reduction in photosynthesis. However, we did not find that limited $\mathrm{P}_{\mathrm{N}}$ was triggered by a reduction in $\mathrm{c}_{\mathrm{i}}($ Fig. 3$)$. Although our method cannot rule out heterogeneity of stomatal opening (patchy stomatal conductance), mango leaves appear homobaric (Terashima et al., 1988). Thus, reduced stomatal conductance under low $\mathrm{pO}_{2}$ in the root zone is a consequence, rather than the cause of a reduced $\mathrm{CO}_{2}$ exchange in mango.

In studies lasting days to weeks, decreasing hydraulic conductivity of roots and subsequent changes in the water status may be more relevant for the response to flooding (Freundl et al., 1998; Syvertsen et al., 1983). A limited water flow from the roots would eventually force stomatal closure and constrain $\mathrm{CO}_{2}$ exchange of the leaves. In short-term flooding studies, however, nonstomatal factors such as the pyridine nucleotide charge may limit photosynthetic rate.

Nonstomatal EFFECTS ON PHOtosynthesis. After an initial increase, reduction rates of phosphorylated and nonphosphorylated pyridine nucleotides in the leaves decreased to near control level within $28 \mathrm{~h}$ of anoxia. Endogenous mechanisms may regulate the electron gradient to maintain an effective cell metabolism. In the photochemical reaction chain, plastoquinone $\left(Q_{A}\right)$ is the electron receptor following PS II (Haumann and Junge, 1999). ETR is limited when $\mathrm{Q}_{\mathrm{A}}$ and the electron transport chain via ferredoxin $\left(\mathrm{E}_{0}=-444 \mathrm{mV}\right)$ to NADP $\left(\mathrm{E}_{0}=-320 \mathrm{mV}\right)$ is already in its reduced state (Krause and Weis, 1991; Schreiber et al., 1995). Fluorescence measurements with and without addition of $\mathrm{NADH}^{+} \mathrm{dem}-$ onstrated directly the associated effects of NADP charge on ETR (Mi et al., 1994; Schreiber et al., 1995).

Results presented here demonstrate that, in the short-term, 
nonstomatal factors limit photosynthesis under anoxia in the root zone. This was indicated by reduced effective photochemical efficiency, while dark fluorescence $\left(\mathrm{F}_{0}\right)$ was enhanced. Increased $\mathrm{F}_{0}$ of dark-adapted leaves is generally considered to be the result of suppressed electron transport, i.e., a partially blocked electron pathway. The limited ETR with increasing irradiance implies reduced capacity of the electron transport chain. We conclude that an increased pyridine nucleotide charge is limiting the photosynthetic rate, possibly by disrupting electron transfer from ferredoxin to NADP ${ }^{+}$. Over longer periods of anoxia, stomatal effects may outweigh the effects of NADP charge.

\section{Literature Cited}

Andersen, P.C., P.B. Lombard, and M.N. Westwood. 1984. Leaf conductance, growth, and survival of willow and deciduous fruit tree species under flooded soil conditions. J. Amer. Soc. Hort. Sci. 109:132138.

Andrews, D.L., D.M. McAlpine, J.R. Johnson, P.M. Kelley, B.G. Cobb, and M.C. Drew. 1994. Differential induction of mRNAs for the glycolytic and ethanolic fermentative pathways by hypoxia and anoxia in maize seedlings. Plant Physiol. 106:1575-1582.

Backhausen, J.E., A. Emmerlich, S. Holtgrefe, P. Horton, G. Nast, J.J.M. Rogers, B. Müller-Röber, and R. Scheibe. 1998. Transgenic potato plants with altered expression levels of chloroplast NADP-malate dehydrogenase, interactions between photosynthetic electron transport and malate metabolism in leaves and in isolated intact chloroplasts. Planta 207:105-114.

Beckman, T.G., R.L. Perry, and J.A. Flore. 1992. Short-term flooding affects gas exchange characteristics of containerized sour cherry trees. HortScience 27:1297-1301.

Biemelt, S., U. Keetman, and G. Albrecht. 1998. Re-aeration following hypoxia or anoxia leads to activation of the antioxidative defense system in roots of wheat seedlings. Plant Physiol. 116:651-658.

Bradford, K.J. and T.C. Hsiao. 1982. Stomatal behavior and water relations of waterlogged tomato plants. Plant Physiol. 70:1508-1513.

Brändle, R.A. 1991. Flooding resistance of rhizomatous amphibious plants, p. 35-46. In: M.B. Jackson, D.D. Davies, and H. Lambers (eds.). Plant life under oxygen deprivation. SPB Academic Publishing, The Hague, The Netherlands.

Brinkman, F.G., L.H.W. van der Plas, and F.D. Verleur. 1973. Pyridine nucleotide levels in potato tuber tissue and its mitochondrial fraction after wounding. Z. Pflanzenphysiol. 68:364-372.

Crawford, R.M.M. 1993. Plant survival without oxygen. Biologist 40:110-163.

Drew, M.C. 1997. Oxygen deficiency and root metabolism: Injury and acclimation under hypoxia and anoxia. Annu. Rev. Plant Physiol. Plant Mol. Biol. 48:223-250.

Dry, I.B. and J.T. Wiskich. 1982. Role of external adenosine triphosphate/adenosine diphosphate ratio in the control of plant mitochondrial respiration. Arch. Biochem. Biophys. 217:72-79.

Freundl, E., E. Steudle, and W. Hartung. 1998: Water uptake by roots of maize and sunflower affects the radial transport of abscisic acid and its concentration in the xylem. Planta 207:8-19.

Gerst, U., G. Schonknecht, and U. Heber. 1994. ATP and NADPH as the driving force of carbon reduction in leaves in relation to thylakoid energization by light. Planta 193:421-429.

Giersch, C., U. Heber, Y. Kobayashi, Y. Inoue, K. Shibata, and H.W. Heldt. 1980. Energy charge, phosphorylation potential and proton motive force in chloroplasts. Biochim. Biophys. Acta 590:59-73.

Hand, S.C. and I. Hardewig. 1996. Downregulation of cellular metabolism during environmental stress: Mechanisms and implications. Annu. Rev. Plant Physiol. 58:539-563.

Hanning, I. and H.W. Heldt. 1993. On the function of mitochondrial metabolism during photosynthesis in spinach leaves (Spinacia oleracea L.). Partitioning between respiration and export of redox equivalents and precursors for nitrate assimilation products. Plant Physiol.
103:1147-1154.

Haumann, M. and W. Junge. 1999. Photosynthetic water oxidation: A simplex-scheme of its partial reactions. Biochim. Biophys. Acta 1411:86-91.

Heineke, D., B. Riens, H. Grosse, P. Hoferichter, U. Peter, U.I. Flügge, and H.W. Heldt. 1991. Redox transfer across the inner chloroplast envelope membrane. Plant Physiol. 95:1131-1137.

Hoffmann, P., G. Walter, E.M. Wiedenroth, and G. Peine. 1993. How the cereals cope with oxygen deficiency. Photosynthetica 28:495-513.

Jackson, M.B. and M.C. Drew. 1984. Effect of flooding on growth and metabolism of herbaceous plants, p. 47-128. In: T.T. Kozlowski (ed.). Flooding and plant growth. Academic Press, Orlando, Fla.

Kennedy, R.A., T.C. Fox, J.D. Everard, and M.E. Rumpho. 1991. Biochemical adaptations to anoxia: Potential role of mitochondrial metabolism to flood tolerance in Echinochloa phyllopogon (barnyard grass), p. 217-227. In: M.B. Jackson, D.D. Davies, and H. Lambers (eds.). Plant life under oxygen deprivation. SPB Academic Publishing, The Hague, The Netherlands.

Kennedy, R.A., M.E. Rumpho, and T.C. Fox. 1992. Anaerobic metabolism in plants. Plant Physiol. 100:1-6.

Kitzman, C. 1996. Regulatorische Wechselwirkung zwischen Pyridinnukleotid- und Adenylat-Pool in intakten isolierten Spinatchloroplasten ('Interaction between pyridine nucleotide and adenylate content in isolated spinach chloroplasts'). $\mathrm{PhD}$ diss. Inst. for Biol., Humboldt Univ. of Berlin, Berlin.

Krause, G.H. and E. Weis. 1991. Chlorophyll fluorescence and photosynthesis: The basics. Annu. Rev. Plant Physiol. Plant Mol. Biol. 42:313-349.

Krömer, S. 1995. Respiration during photosynthesis. Annu. Rev. Plant Physiol. Plant Mol. Biol. 46:45-70.

Kwast, K.E. and S.C. Hand. 1996. Acute depression of mitochondrial protein synthesis during anoxia-Contributions of oxygen sensing, matrix acidification and redox state. J. Biol. Chem. 271:7313-7319.

Laisk, A., K. Siebke, U. Gerst, H. Eichelmann, V. Oja, and U. Heber. 1991. Oscillations in photosynthesis are initiated and supported by imbalances in the supply of ATP and NADPH to the calvin cycle. Planta 185:554-562.

Lambers, H., A. Van der Werf, and K. Konings. 1991. Respiratory patterns in relation to their functioning, p. 229-264. In: Y. Waisel, A. Eshel, and U. Kafkafi (eds.). Plant roots: The hidden half. Marcel Dekker, New York.

Larson, K.D. 1992. Flooding, mineral nutrition and gas exchange of mango trees. Scientia Hort. 52:113-124.

Larson, K.D. and B. Schaffer. 1991. Flooding, leaf gas exchange, and growth of mango in containers. J. Amer. Soc. Hort. Sci. 116:156-160. McIntyre, M. and B. McNeil. 1997. Dissolved carbon dioxide effects on morphology, growth, and citrate production in Aspergillus niger A60. Enzyme and Microbial Technol. 20:135-142.

Mi, H.L., T. Endo, U. Schreiber, T. Ogawa, and K. Asada. 1994. NAD(P)H dehydrogenase-dependent cyclic electron flow around photosystem I in the cyanobacterium Synechocystis PCC 6803: A study of dark-starved cells and spheroplasts. Plant Cell Physiol. 35:163-173.

Möller, I.M. and W. Lin. 1986. Membrane-bound NAD(P)H dehydrogenases in higher plant cells. Annu. Rev. Plant Physiol. 37:309-334.

Paul, R.J. and H. Schneckenburger. 1996. Oxygen concentration and the oxidation-reduction state of yeast: Determination of free/bound NADH and flavins by time-resolved spectroscopy. Naturwissenschaften 83:3235.

Peine, G., P. Hoffmann, G. Seifert, and G. Schilling. 1985. Pyridine nucleotide pattern and reduction charge in wheat seedlings with special regard to different photosynthetic conditions. Biochem. Physiol. Pflanzen 180:1-14.

Perata, P. and A. Alpi. 1993. Plant responses to anaerobiosis. Plant Sci. 93:1-17.

Pezeshki, S.R., J.H. Pardue, and R.D. De Laune. 1996. Leaf gas exchange and growth of flood-tolerant and flood-sensitive tree species under low soil redox conditions. Tree Physiol. 16:453-458.

Pfister-Sieber, M. and R. Brändle. 1994. Aspects of plant behaviour 
under anoxia and post-anoxia. Proc. Royal Soc. Edinburgh. Sect. B, Biol. Sci. 102:313.

Ponnamperuma, F.N. 1972. The chemistry of submerged soils. Adv. Agron. 24:29-96.

Popova, T.N. and M.A.A. Pinheiro de Carvalho. 1998. Citrate and isocitrate in plant metabolism. Biochim. Biophys. Acta 1364:307-325.

Pradet, A. and P. Raymond. 1983. Adenine nucleotide ratios and adenylate energy charge in energy metabolism. Annu. Rev. Plant Physiol. 34:199-234.

Rao, I.M., A.R. Arulanantham, and N. Terry. 1990. Diurnal changes in adenylates and nicotinamide nucleotides in sugar beet leaves. Photosyn. Res. 23:205-212.

Rao, I.M. and N. Terry. 1994. Leaf phosphate status and photosynthesis in vivo: Changes in sugar phosphates, adenylates and nicotinamide nucleotides during photosynthetic induction in sugar beet. Photosynthetica 30:243-254.

Ricard, B., I. Couée, P. Raymond, P.H. Saglio, V. Saint-Ges, and A. Pradet. 1994. Plant metabolism under hypoxia and anoxia. Plant Physiol. Biochem. 32:1-10.

Rumpho, M.E., and R.A. Kennedy. 1983a. Activity of the pentose phosphate and glycolytic pathways during anaerobic germination of Echinochloa crus-galli (barnyard grass) seeds. J. Expt. Bot. 34:893902.

Rumpho, M.E. and R.A. Kennedy. 1983b. Anaerobiosis in Echinochloa crus-galli (barnyard grass) seedlings. Plant Physiol. 72:44-49.

Schaffer, B., A.W. Whiley, and J.H. Crane. 1994. Mango, p. 165-197. In: B. Schaffer and P.C. Anderson (eds). Handbook of environmental physiology of fruit crops. CRC Press, Boca Raton, Fla.

Scheibe, R. 1991. Redox-modulation of chloroplast enzymes: A common principle for individual control. Plant Physiol. 96:1-3.

Schreiber, U., H. Hormann, C. Neubauer, and C. Klughammer. 1995. Assessment of photosystem II photochemical quantum yield by chlorophyll fluorescence quenching analysis. Austral. J. Plant Physiol. 22:209-220.

Siebke, K., A. Laisk, V. Oja, O. Kiirats, K. Raschke, and U. Heber. 1990. Control of photosynthesis in leaves as revealed by rapid gas exchange and measurements of the assimilatory force $\mathrm{F}_{\mathrm{A}}$. Planta 182:513-522.

Summers, J.E. and M.B. Jackson. 1996. Anaerobic promotion of stem extension in Potamogeton pectinatus: Roles for carbon dioxide, acidification and hormones. Physiol. Plant. 96:615-622.

Syvertsen, J.P., R.M. Zablotowicz, and M.L. Smith. 1983. Soil temperature and flooding effects on two species of citrus. I. Plant growth and hydraulic conductivity. Plant and Soil 72:3-12.

Terashima, I., S.C. Wong, C.B. Osmond, and G.D. Farquhar. 1988. Characterisation of non-uniform photosynthesis induced by abscisic acid in leaves having different mesophyll anatomies. Plant Cell Physiol. 29: 385-394.

Trolldenier, G. and C. Hecht-Buchholz. 1984. Effect of aeration status of nutrient solution on microorganisms, mucilage and ultrastructure of wheat roots. Plant Soil 80:381-390.

Vu, J.C.V. and G. Yelenosky. 1991. Photosynthetic responses of citrus trees to soil flooding. Physiol. Plant. 81:7-14.

White, A.J. and C. Critchley. 1999. Rapid light curves: A new fluorescence method to assess the state of the photosynthetic apparatus. Photosyn. Res. 59:63-72.

Wigge, B., S. Krömer, and P. Gardeström. 1993. The redox levels and subcellular distribution of pyridin nucleotides in illuminated barley leaf protoplasts studied by rapid fractionation. Physiol. Plant. 88:1018.

Zhao, Z., X. Hu, and C.W. Ross. 1987. Comparison of tissue preparation methods for assay of nicotinamide coenzymes. Plant Physiol. 84:987988.

Zude-Sasse, M. 1999. Einfluss von temporär reduziertem Sauerstoffpartialdruck in der Wurzelzone auf den Reduktionsgrad von NAD(P) und die Photosynthese bei Mango, sowie Wechselwirkungen mit der Eisenernährung bei Mango und Citrus (Influence of temporarily reduced oxygen partial pressure in the rootzone on rate of reduction of $\mathrm{NAD}(\mathrm{P})$ and photosynthesis of mango and interaction with the iron supply of mango and citrus). PhD diss. Humboldt Univ. of Berlin, Berlin.

Zude-Sasse, M., G. Ebert, and P. Lüdders. 1998. Influence of flooding on growth and gas exchange of mango rootstocks (Mangifera indica L.) and proposed selection criteria for flood tolerance. Appl. Bot. 72:148151.

Zude-Sasse, M. and P. Lüdders. 2000. Citrus root responses to anoxia. Acta Hort. 531:121-128. 